\title{
OLAHAN KUNYIT ASAM MENJADI MINUMAN HERBAL SINOM UNTUK MENINGKAT PEREKONOMIAN DESA KAJUANAK GALIS BANGKALAN
}

\author{
Kholid. Mudarris, Masdar \\ STAI Darul Hikmah Bangkalan \\ kholidpinggiran@darul-hikmah.com, darrisnice@gmail.com, \\ masdar@darul-hikmah.com
}

\begin{abstract}
ABSTRAK
Desa Kajuanak merupakan salah satu dari desa yang berada di Kecamatan Galis Kabupaten Bangkalan, dimana Untuk sector pertanian dan perkebunannya, Desa Kajuanak merupakan penghasil kunyit yang cukup besar di Kecamatan Galis. Namun, pengolahan yang dilakukan oleh masyarakat Desa Kajuanak masih sangat tradisional, yaitu hanya menjual hasil pertanian atau perkebunannya tersebut tanpa dibuat bahan lain yang bernilai ekonomis. Mengingat kandungan yang sangat besar itu, serta cara masyarakat Kajuanak dalam memasarkan hasil tanamannya, maka mahasiswa KKN Desa Kajuanak memberikan salah satu programnya yaitu dengan menjadikan bahan dasar dalam pembuatan minuman herbal sinom yang terbuat dari kunyi dan tentunya mempunyai nilai ekonomis dalam pengembangan perekonomian masyarakat Desa Kajuanak. Manfaat besar yang dapat diambil dari program kegiatan ini adalah mengembangkan taraf hidup masyarakat Desa Kajuanak dengan ekonomi kreatif sebagai upaya yang dapat dijadikan sebagai bentuk peningkatan perekonomian masyarakat. Keberadan kunyit yang semula hanya dijual dipasar-pasar tradisional, dengan adanya produk olahan ini, kunyit para petani Desa Kajuanak dapat dikenal oleh masyarakat luas.
\end{abstract}

Kata kunci: olahan kunyit, perekonomian 


\section{A. ANALISIS MASALAH}

Desa Kajuanak merupakan salah satu dari desa yang berada di kecamatan Galis kabupaten Bangkalan. Desa ini kurang lebih terletak 33 km dari Kabupaten Bangkalan dan memerlukan waktu tempuh selama kurang lebih 1jam 7 menit.. Sebelah utara desa Kajuanak berbatasan dengan desa Paterongan, sebelah barat desa Kajuanak berbatasan dengan desa Pekadan, sebelah timur desa Kajuanak berbatasan dengan desa gigir, sebelah selatan desa Kajuanak berbatasan dengan desa Suwa'an

Untuk sector pertanian dan perkebunannya, Desa Kajuanak merupakan penghasil kunyit yang cukup besar di Kecamatan Galis. Namun, pengolahan yang dilakukan oleh masyarakat Desa Kajuanak masih sangat tradisional, yaitu hanya menjual hasil pertanian atau perkebunannya tersebut tangpa dibuat bahan lain yang bernilai ekonomis.

Mayoritas perekonomian Desa Kajuanak sebesar 45\% bekerja sebagai petani, sedangkan $8 \%$ sebagai pedagang dan $40 \%$ merantau baik keluar kota maupun negara. Keadaan fisik tanah yang terdapat di desa Kajuanak umumnya berwarna merah. Tekstur tanahnya berupa pasir, berbatu dan berlumpur. Kondisi iklim di desa Kajuanak dapat dikatakan baik dan mendukung bagi pertanian warga. Luas tanah kurang lebih 3,450 H. Pada umumnya dimusim hujan petani sebagian besar menanam padi, disamping itu sebagian besar masysrakat Desa Kajuanak juga menanam tanaman obat, yaitu kunyit.

Kunyit yang dalam Bahasa latinnya adalah curcuma longa linn adalah salah satu tanaman rempah dan obat yang berasal dari wilayah Asia Tenggara. Tanaman ini mengalami penyebaran ke daerah Malaysia, Indonesia, Australia bahkan sampai pada Afrika. Kebiasan orang 
Indonesia umumnya menggunakan kunyit sebagai pelengkap masakan, jamu atau untuk menjaga Kesehatan. Kunyit tergolong dalam kelompok jahe-jahean, Zingiberaceae. Kunyit dikenal di berbagai daerah dengan beberapa nama lokal, seperti, turmeric (Inggris), kurkuma (Belanda), kunyit (Indonesia dan Malaysia), janar (Banjar), kunir (Jawa), koneng (Sunda), konyet (Madura), kunyir (Komering).

Manfaat serta kandungan yang terdapat pada tanaman kunyit ini sangat banyak sekali, seperti adanya kandugan kurkumin, sesmetoksikumin, bisdesmetoksikurkumin, resim, pati, karbohidrat, protein, selulosa, dan lemak, serta diperkaya dengan vitamin c, antioksidan, zat pahit, zat besi, fosfor, kalsium, hingga minyak atsiri.

Saat dilakukan observasi pada masyarakat Desa Kajuanak, mereka menyampaikan bahwa hasil tanaman kunyitnya hanya dijual di pasar dan beberapa toko sekitar. Harga yang di dapat dipasaran sangatlah murah dan tidak sesuai dengan biaya perawatan saat menanam tanaman kunyit.

Mengingat kandungan yang sangat besar itu, serta cara masyarakat Kajuanak dalam memasarkan hasil tanamannya, maka mahasiswa KKN Desa Kajuanak memberikan salah satu programnya yaitu dengan menjadikan bahan dasar dalam pembuatan minuman herbal sinom yang terbuat dari kunyi dan tentunya mempunyai nilai ekonomis dalam pengembangan perekonomian masyarakat Desa Kajuanak.

Tidak hanya itu, dari pengolahan bahan dasar kunyit tersebut, nantinya akan menjadi bahan pelatihan bagi masyarakat Desa Kajuanak dalam mengolah dan membuat minuman herbal sinom berbahan dasar kunyit, sehingga keberadaan mahasiswa KKN di Desa Kajuanak ini dapat membantu pula mengembangkan perekonomian di Desa Kajuanak. 


\section{B. METODE}

Pemberdayaan masyarakat dalam pengabdian masyarakat ini, dilakukan melalui program-program yang telah dirancang sebelumnya saat melakukan observasi awal di Desa Kajuanak. Hal ini dimaksudkan untuk lebih memahami dan mendapatkan hasil yang maksimal dalam pelaksaan pelatihan dengan metode pendampingan. Metode ini sangat cocok digunakan demi tercapainya tujuan dalam sebuah program yang telah ada. Adapun tahapan yang dilakukan saat pelatihan dan pendampingan tersdiri dari : persiapan, riset dan formulasi produk, pelatihan dan pendampingan.

a. Persiapan

Pada tahapan ini, Mahasiswa KKN melakukan kunjungan ke rumahrumah warga masyarakat Kajuanak untuk melihat langsung hasil pertanian dari tanaman kunyit ini.

Berikut gambar saat melakukan observasi awal pada salah satu masyarakat yang sudah memanen tanaman kunyitnya.

\section{Gambar. 1}

Observasi kepada petani tanaman kunyit
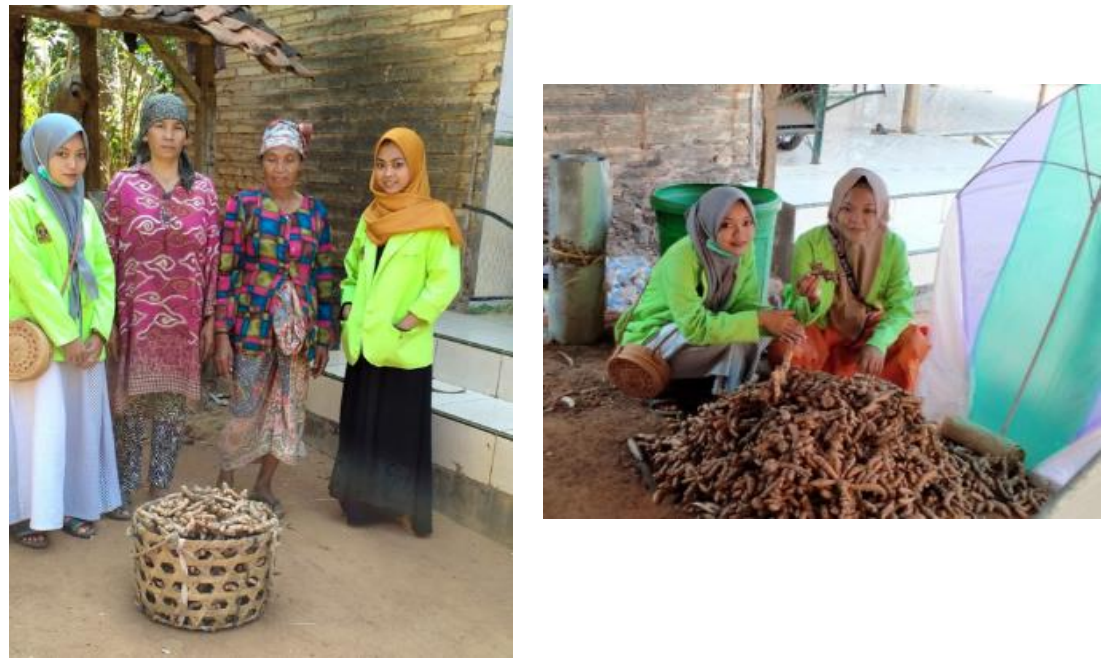
b. Riset dan Formulasi Produk

Pada tahapan ini, Mahasiswa KKN melakukan penelitan terlebih dahulu, untuk mengetahui hasil yang di dapat dari olahan kunyit tersebut. Disamping itu juga para Mahasiswa menguji pangsa pasar yang berada di sekitar Desa Kajuanak. Tahapan ini selanjutnya memformulasikan dengan beberapa uji coba agar menemukan komposisi yang sesuai dan seimbang sehingga rasa yang dihasilkan dapat diminati oleh masyarakat sekitar.

\section{Gambar 2}

saat melakukan formulasi dalam pembuatan olahan kunyit.

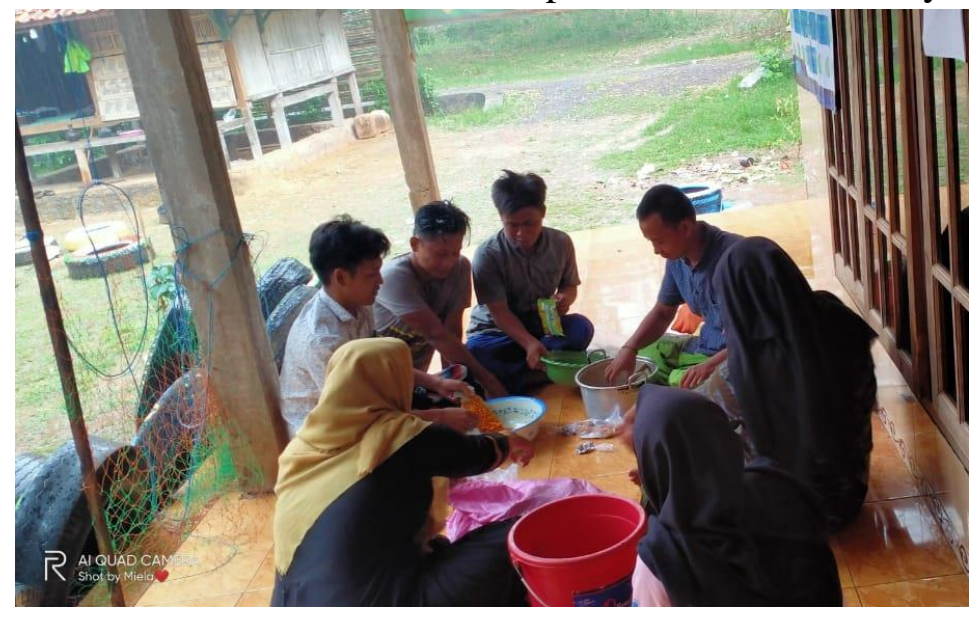

c. Pelatihan dan Pendampingan

Tahapan ini merupakan tahapan terakhir dari metodi pelatihan dan pendampingan, dikatan demikian karena pada tahapan ini. Mahasiswa KKN sudah menemukan produk olaharn yang sesuai dan diminati oleh masyarakat sekitar.

Selanjutnya, pada tahapan ini analisis strategi pemasaran sudah mulai dilakukan oleh para Mahasiswa, yaitu dengan memberikan hasil olahan kunyit kepada toko-toko UMKM yang berada di Desa 
Kajuanak. Hasil yang didapat adalah adanya ketertarikan dari pemilik toko untuk memsarkan produk olahan tersebut.

\section{HASIL DAN PEMBAHASAN}

Hasil dari pelatihan dan pendampingan dalam produk olahan di Desa Kajuanak ini berawal dari program yang telah tersusun oleh mahasiswa KKN. Selain itu, melihat kondisi dari perekonomian dan kebiasan Masyarakat Desa Kajuanak dalam mengolah dan mesarkan hasil tanaman kunyit, maka pelatihan dan pendampingan ini menjadi salah satu program yang dapat mengembangkan perekonomian masyarakat Desa Kajuanak.

Tahapan awal yang dilakukan adalah melakukan persiapan dengan mendatangi warga masyarakat yang sedang memanen tanaman kunyit, mencari informasi tentang kunyit setelah dipanen, serta mencari informasi tentang olahan-olahan dari bahan dasar kunyit yang diminati, masyarakat.

Dari hasil informasi yang di dapat menunjukkan bahwa hasil tanaman kunyit masyarakat Desa Kajuanak hanya dijual di pasar tradisional, dan itupun dengan harga yang sangat murah, berkisar 40.000 sampai 50.000/ keranjang. Hal ini sangat jauh dari untung yang diharapkan oleh para petani kunyit.

Mengingat pentingnya pertumbuhan perekonomian masyarakat yang menjadi salah satu program dari $\mathrm{KKN}$ ini, sehingga mahasiswa KKN memberikan program kegiatan yang mngolah tanaman kunyit menjadi bahan olahan minuman sinom yang layak jual dan bernilai ekonomis.

Sebelum pelatihan dan pendampingan dari olahan kunyit dilakukan, para Mahasiswa melalukan tahapan beberapa uji coba, guna 
mencari formulasi yang tepat dan sesuai dengan keinginan masyarakat sekitar. Dari hasil formasi tersebut didapat bahan dasar tambahan yang menjadikan olahan kunyit ini menjadi menarik dan disukai oleh masyarakat.

Adapun bahan-bahan yang digunakan dalam pembutan olahan kunyit menjadi minuman sinom adalah sebagai berikut :

○ 21 air

○ $75 \mathrm{~g}$ sinom (masih dengan tangkai)

○ 75 g asam jawa

○ 50 g kunyit, kupas, memarkan

○ 100 g gula merah2

- 100 g gula pasir

Cara mengolahannya adalah dengan merebus air bersama daun sinom, asam jawa, dan kunyit di atas api kecil hingga mendidih. Masukkan gula merah dan gula pasir. Aduk hingga larut, angkat. Diamkan hingga tidak panas, saring. Didihkan kembali. Angkat. Sajikan saat hangat.

Manfaat dan khasiat dari bahan-bahan di atas sangat banyak sekali, diantaranya ialah:

○ Antiseptik

○ Antioksidan

○ Mengatasi masuk angin

○ Mengurangi nyeri saat haid

- Mengobati sembelit

○ Kontrol gula darah

- Menutunkan tekanan darah

- Melancarkan pernapasan 
Disamping itu juga, manfaat asam jawa dalam bahan pembuatan produk sinom tersebut juga banyak sekali, diantaranya :

- Menurunkan berat badan Berat badan

- Membantu perkembangan otot dan saraf

- Pencegahan ulkus Hanya sistem pencernaan yang sehat yang akan membantu menyerap nutrisi secara maksimal. Ulkus dapat dicegah dengan asam Jawa secara teratur. Ekstrak biji asam mengandung senyawa yang menghambat terjadinya bisul.

- Mencegah kanker Kanker disebabkan karena pertumbuhan sel-sel yang berkembang pada radikal bebas. Sebagai pembangkit energi antioksidan, asam Jawa akan meningkatkan antioksidan di dalam tubuh dan menghilangkan sel kanker.

- Antihistamin Asam jawa juga membantu melawan pilek dan flu. Ini biasanya disebabkan oleh alergi atau infeksi virus. Namun, asam Jawa memiliki sifat antihistamin yang membantu mencegah serangan asma dan jenis pilek dan flu lainnya.

Setelah tahapan formulasi selesai, selanjutnya para Mahasiswa melakukan pelatihan dan pendampingan kepada masyarakat Desa Kajuanak. Tahapan ini menajadi sangat penting, karena dari produk olahan kunyit yang menjadi minuman sinom ini nantinya juga akan diberikan pelatihan bagaimana cara memasarkan kepada para konsumen.

\section{Gambar 3}

Pelatihan dan Pendampingan Produk Sinom

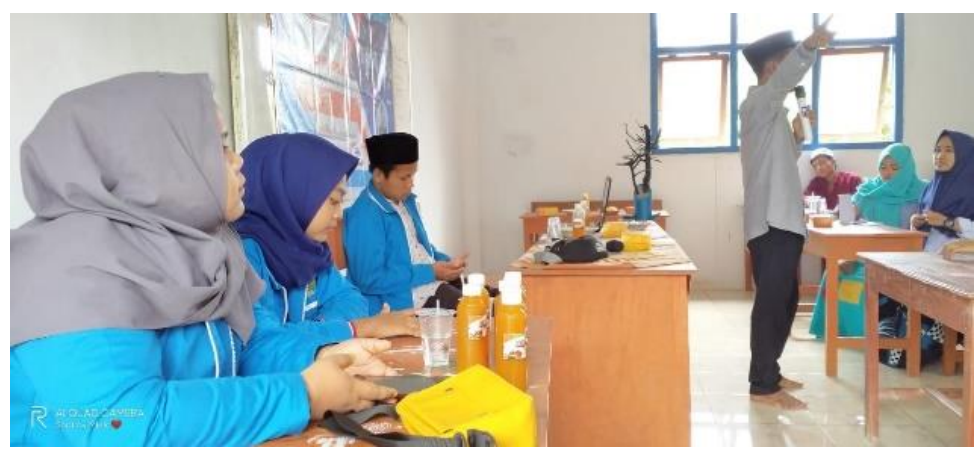




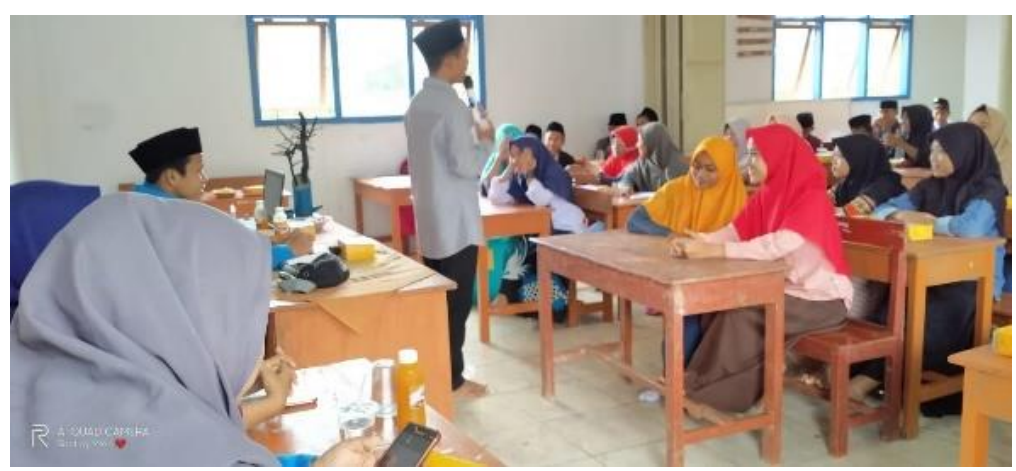

Selain itu, untuk memberikan kesempatan yang seluas-luasnya kepada masyarakat saat pelatihan tersebut, diberikan pula pelatihan mengenai strategi pemasaran produk minuman sinom. Pemanfaatan awal dari produk sinom ini adalah dengan memasarkan pada toko-toko UMKM masyarakat sekitar. Hal ini dilakukan untuk membantu perekonomian masyarakat Kajuanak yang berprofesi sebagai pedagang kecil. Selanjutnya, pemasaran dilakukan dengan menggunakan media online yang saat ini mejadi akses yang cepat dalam pemasaran produk, diantara melalui facebook, Instagram, Whatsapp. Strategi pemasaran online (online marketing strategy) merupakan segala bentuk usaha yang berkaitan dengan bisnis guna memasarkan suatu produk ataupun jasa melalui media online yakni internet (Setiawati \& Widyartati, 2017).

Tidak hanya sampai disini, para Mahasiswa Bersama masyarakat Kajuanak melakukan prosesn branding dengan memberikan merk pada produk minuman sinom, yang tujuannya adalah agar produk olahan kunyit menjadi menjadi minuman herbal sinom ini dapat dikenali oleh masyarakat luas, sehingga mempunyai nilai jual yang sangat terhadap para konsumen. 


\section{Gambar 4.}

Packing produk minuman sinom

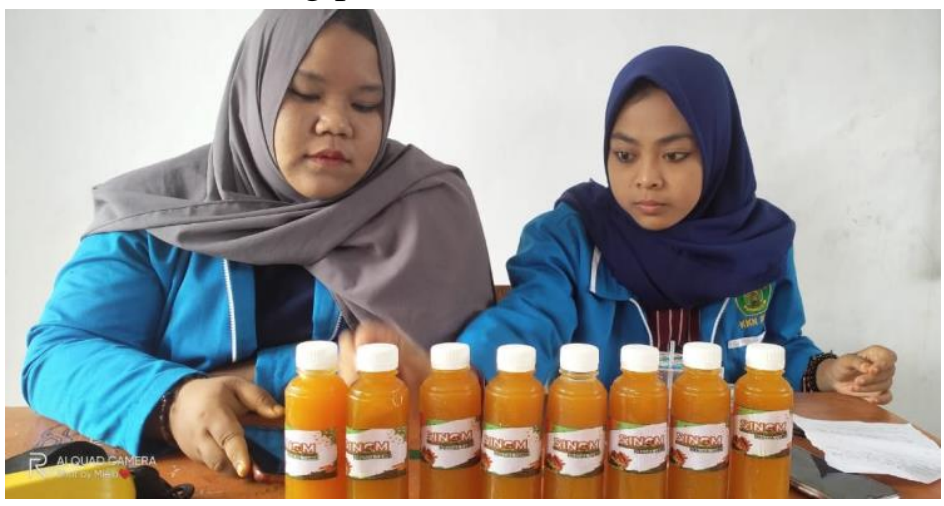

Manfaat besar yang dapat diambil dari program kegiatan ini adalah mengembangkan taraf hidup masyarakat Desa Kajuanak dengan ekonomi kreatif sebagai upaya yang dapat dijadikan sebagai bentuk peningkatan perekonomian masyarakat. Keberadan kunyit yang semula hanya dijual dipasar-pasar tradisional, dengan adanya produk olahan ini, kunyit para petani Desa Kajuanak dapat dikenal oleh masyarakat luas.

\section{KESIMPULAN}

Melalui program KKN yang dilaksanakan oleh Mahasiswa STAI Darul Hikmah di Desa Kajuanak ini dapat memberikan penambahan wawasan kepada masyarakat kajuanak untuk melakukan ekonomi kreatif guna meningkatkan perekonomian masyarakat di Desa Kajuanak.

Hal tersebut terlihat dari adanya perubahan pola ekonomi masyarakat, yang semula hanya memasarkan dan menjual pada pasar tradisional, dengan adanya olahan kunyit menjadi minuman herbal sinom ini, perekonomian masyarakat dapat ditingkatkan, bukan hanya pada masyarakat sekitar saja, namun pada khalayak masyarakat luas.

Harapan terbesar adalah agar nantinya olahan-olahan serta inovasi-inovasi yang lebih terbarukan dapat menjadikan masyarakat 
Desa Kajuanak menjadi masyarakat yang penuh dengan pola ekonomi kreatif, sehingga perekonomiannyapun akan selalu meningkat.

\section{E. UCAPAN TERIMA KASIH}

Program kegiatan ini terselenggara atas partisipasi serta kerjasama aparatur Desa Kajuanak dan Tokoh Masyarakat serta dinas terkait. Untuk itu kami ucapkan terimakasih sedalam-dalamnya kepada persngkat Desa Kajuanak yang telah memberikan support dan dukungan yang begitu luar biasa, sehingga pelaksanaan program kegiatan ini berjalan lancar dan sukses.

Tak lupa lupa ucapa terimakasih terhaturkan kepada masyarakat Desa kajuanak yang menjadi sasaran terselenggaranya program kegiatan ini. Serta ucapan terimakasih kami sampaikan kepada Kelompok II Mahasiswa KKN STAI Darul Hikmah Bangkalanyang secara khusus, telah memotori terselenggaranya kegiatan ini mulai dari tahap peersiapan hingga penyusunan laporan kegiatan 


\section{DAFTAR PUSTAKA}

Budhyantoro, Arief. "MERINTIS BRANDING "KAMPUNG JAHE MOJOKERTO (KJM)" DI DESA GADING KECAMATAN JATIREJO, KABUPATEN MOJOKERTO." Edupreneur: Jurnal Pengabdian kepada Masyarakat bidang Kewirausahaan 2.2 (2019).

Hendarto, M. Si, and Ir Totok. "IMPLEMENTASI MANAJEMEN PEMASARAN USAHA MINUMAN SINOM KEKINIAN." (2019).

Indrayani, Siska, and Indah Setia Ningsih. "Efektifitas Ekstrak Kunyit dalam Mengurangi Nyeri Dismenorhea pada Mahasiswi di Asrama Akademi Kebidanan Salma Siak." Menara Ilmu 12.5 (2018).

Pudiastutiningtyas, Nurul, et al. "Diversifikasi Kunyit (Curcuma domestica) dan Kencur (Kaempferia galanga L.) Sebagai Minuman Herbal Serbuk Siap Saji." METANA 11.01 (2015).

Ramdhan, T. W., \& Kholid, M. (2019). PENGOLAHAN LIMBAH KULIT RAMBUTAN MENJADI PRODUK MINUMAN DALAM MENINGKATKAN PEREKONOMIAN MASYARAKAT DESA RONG DURIN KABUPATEN BANGKALAN. As-Sidanah: Jurnal Pengabdian Masyarakat, 1(1), 96-102.

Said, Ahmad. Khasiat dan manfaat kunyit. Ganeca Exact, 2007 